\author{
$\mathrm{Mg}-\mathrm{Zn}$ 합금의 압출 공정 중 동적 석출 거동에 대한 고찰 \\ 이광철 1,5 · 나민영 2 장혜정 2,3 · 차필령 4 - 김유찬 $1,5, *$. 석현광 $1,6, *$ \\ 1과학기술연합대학원대학교 키스트 스쿨 바이오-메디컬 융합 공학부 \\ 2 한국과학기술연구원 특성분석센터 \\ 3과학기술연합대학원대학교 키스트 스쿨 나노-정보기술 공학부 \\ 4국민대학교 신소재공학부 \\ 5한국과학기술연구원 의공학연구소 생체재료연구단 \\ ${ }^{6}$ 한국과학기술연구원 의공학연구소
}

\title{
Evaluation of Dynamic Precipitation in Extruded Mg-Zn Alloy
}

\author{
Guang Zhe Li ${ }^{1,5}$, Min Young $\mathrm{Na}^{2}$, Hye Jung Chang ${ }^{2,3}$, Pil Ryung Cha ${ }^{4}$, Yu Chan Kim ${ }^{1,5}$, , and Hyun Kwang Seok ${ }^{1,6, *}$ \\ ${ }^{1}$ Division of Bio-Medical Fusion, KIST school, University of Science and Technology (UST), Seoul 02792, Republic of Korea \\ ${ }^{2}$ Advanced Analysis Center, Korea Institute of Science and Technology, Seoul 02792, Republic of Korea \\ ${ }^{3}$ Division of Nano \& Information Technology, KIST school, University of Science and Technology (UST), Seoul 02792, \\ Republic of Korea \\ ${ }^{4}$ Division of Advanced Material Engineering, Kookmin University, Seoul 02707, Republic of Korea \\ ${ }^{5}$ Center for Biomaterials, Biomedical Research Institute, Korea Institute of Science and Technology, Seoul 02792, Republic of Korea \\ ${ }^{6}$ Biomedical Research Institute, Korea Institute of Science and Technology, Seoul 02792, Republic of Korea
}

\begin{abstract}
The dynamic precipitation evolution of $\mathrm{Mg}-3 \mathrm{wt} \% \mathrm{Zn}$ alloy during extrusion was evaluated in this study. Precipitation evolution during aging has been well investigated for the Mg-Zn alloy, which is known as static precipitation. However, little attention has been given to dynamic precipitation in $\mathrm{Mg}-\mathrm{Zn}$ alloy. In order to evaluate the dynamic precipitation evolution, $\mathrm{Mg}-3 \mathrm{wt} \% \mathrm{Zn}$ alloy was prepared in an electrical resistance melting furnace and extruded at $180{ }^{\circ} \mathrm{C}$ by direct extrusion. The microstructure of the as-extruded Mg-3 wt\% Zn alloy was investigated by Optical Microscopy (OM), Scanning Electron Microscopy (SEM) and Transmission Electron Microscopy (TEM). A bi-modal crystal structure was observed after extrusion, which consisted of dynamically recrystallized (DRX) regions and deformed regions. The $2^{\text {nd }}$ phases that precipitated during the extrusion were distributed in the dynamically recrystallized regions. The precipitates were mainly $\mathrm{Mg}_{7} \mathrm{Zn}_{3}$ phase, which is known as a metastable phase, and it was determined that the factor influencing the precipitates' formation and distribution during extrusion was dominantly dislocation. Also, the corresponding mechanical properties were investigated by measuring the Vickers hardness and compared with as-cast $\mathrm{Mg}$ $3 \mathrm{wt} \% \mathrm{Zn}$ alloy after aging at $160{ }^{\circ} \mathrm{C}$. The Vickers hardness of the as-extruded $\mathrm{Mg}-3 \mathrm{wt} \% \mathrm{Zn}$ alloy was 81.5 $\mathrm{HV}$, which was $36.7 \%$ higher than that of the as-cast one after aging at $160{ }^{\circ} \mathrm{C}$. This was attributed to grain refinement and dynamic precipitation during severe plastic deformation.
\end{abstract}

(Received May 13, 2019; Accepted July 8, 2019)

Keywords: dynamic precipitation, extrusion, $\mathrm{Mg}-\mathrm{Zn}$ alloy, $\mathrm{Mg}_{7} \mathrm{Zn}_{3}$ phase

\section{1. 서 론}

- 이광철: 박사과정, 나민영: 연구원, 장혜정·김유찬·석현광: 교수/연구원, 차필령: 교수

*Corresponding Author: Yu Chan Kim

[Tel: +82-2-958-5457, E-mail: chany@kist.re.kr]

${ }^{*}$ Corresponding Author: Hyun Kwang Seok

[Tel: +82-2-958-6738, E-mail: drstone@kist.re.kr]

Copyright (C) The Korean Institute of Metals and Materials
마그네슘 합금은 경량성, 진동 흡수성, 전자파 차폐성, 기계적 절삭성 등 특성이 우수하여 자동차, 우주항공, 전자 제품과 같은 경량 구조용 소재 분야에 보급되어 사용하고 있다. 마그네슘합금 중 $\mathrm{Mg}-\mathrm{Zn}$ 계 합금은 우수한 강도와 연 성의 조합을 가지는 합금으로, 특히 $\mathrm{ZK} 60$ 은 $300 \mathrm{MPa}$ 의 
인장강도와 $30 \%$ 의 연신율의 우수한 물성으로 주목을 받 고 있다 [1]. ZK60의 물성에 가까운 $300 \mathrm{MPa}$ 의 인장강도 와 $28 \%$ 의 연신율을 가진 ZK30 합금이 개발되면서 ZK60 과 더불어 알루미늄 합금의 대체품으로서 가장 적합한 소 재로 간주되고 있다 [2]. $\mathrm{ZK}$ 계열 합금의 물성이 향상된 이유는 $\mathrm{Zn}$ 와 $\mathrm{Zr}$ 에 의한 고용강화와 결정립 입계에 의한 강화 및 석출강화이다. 특히, 주된 강화기구인 석출강화는 전위와 석출상의 상호작용을 이용하여 강도를 향상시키는 강화 기구이며 많은 연구가 수행되었다 [1-9]. 기존의 연구 는 대체로 열처리를 통한 시효처리공정에 치중되어 있으며 $\mathrm{Mg}-\mathrm{Zn}$ 합금의 석출거동을 열처리 시간에 따라 다음과 같 은 5 단계로 구분하고 있다 [3].

Super-Sarerated Solid Solution (ssss) $\rightarrow$ Guinier Prestion (G.P.) Zones $\rightarrow \dot{\beta_{1}}\left(\mathrm{Mg}_{4} \mathrm{Zn}_{7}, \mathrm{MgZn}_{2}\right) \rightarrow \dot{\beta_{2}}$ $\left(\mathrm{MgZn}_{2}\right) \rightarrow \beta\left(\mathrm{MgZn}, \mathrm{Mg}_{2} \mathrm{Zn}_{3}\right)$

여기에서 $\mathrm{MgZn}_{2}$ 상은 $\mathrm{C} 14$ 결정구조를 가지고 있으며 $\mathrm{Mg}_{4} \mathrm{Zn}_{7}$ 상은 Monoclinic결정구조를, $\mathrm{MgZn}$ 상은 rhombohedral 구조를 가진다 [10]. 그리고 고온석출상으로 orthorhombic 결정구조를 가진 $\mathrm{Mg}_{7} \mathrm{Zn}_{3}$ 상이 있는데 $\mathrm{Mg}$ - $\mathrm{Zn}$ 합금의 주조재 에서 정출된다고 보고 되었다 [11-14]. 이처럼 열처리공정 을 통해 일어나는 석출을 정적석출 (static precipitation)[9] 이라고 하며 석출을 가속화 하기 위하여 많은 연구자들은 제3원소를 첨가하는 등의 연구를 진행하였다. C.L. Mendis et. al. [3]은 $\mathrm{Ag}$ 와 $\mathrm{Ca}$ 를 $\mathrm{Mg}-6 \mathrm{wt} \% \mathrm{Zn}$ 합금에 첨가하여 석출상의 미세조직을 개선하였으며 이를 통해 경도를 $70 \%$ 이상 향상시켰다고 보고하였다. 또한 열처리를 통한 정적 석출과는 달리 열간소성변형에서 일어나는 석출현상을 동 적석출 (dynamic precipitation) [15]이라고 하는데, $\mathrm{MgZn}_{2}$ 상과 $\mathrm{Mg}_{4} \mathrm{Zn}_{7}$ 상이 열간소성가공 중 동적석출에 의하 여 석출되는 현상은 여러 논문에서 보고 되어 있다 $[16,17]$. Y.Z. Du et. al. [18]은 Mg-Zn-Ca합금으로 압출공정에서 일 어나는 동적석출거동에 대하여 연구하였으며 동적석출의 메커니즘이 정적석출과 다르다고 보고하였다. 최근에 동적 석출이 주목을 받으면서 동적석출에 의한 강화가 물성향상 에 더 효과적이라고 보고 되기도 하였다 [19-21]. 하지만 여전히 $\mathrm{Mg}-\mathrm{Zn}$ 합금의 동적석출거동에 대한 연구는 미미하 며 [22-24] 특히, $200{ }^{\circ} \mathrm{C}$ 이하의 저온소성변형에서 일어나 는 동적석출거동에 대한 연구는 거의 없다 [9]. 이에 본 논문에서는 $\mathrm{Mg}-3 \mathrm{wt} \% \mathrm{Zn}$ 합금을 저온에서 압출 시 일어 나는 동적석출거동과 미세조직의 변화 및 이를 통해 변화 되는 압출재의 물성에 관한 연구를 수행하였다.

\section{2. 실험 방법}

\section{1. 시편 준비}

$\mathrm{Mg}-3 \mathrm{wt} \% \mathrm{Zn}$ 합금은 고순도 $\mathrm{Mg}(99.98 \mathrm{wt} \%), \mathrm{Zn}$ $(99.99 \mathrm{wt} \%)$ 를 원소재로 사용하여 주조하였다. 주조는 전 기용해로에서 수행되었으며 아르곤가스 $(99.999 \%)$ 를 보호 가스로 사용하였다. 시편은 장입 후 $750{ }^{\circ} \mathrm{C}$ 의 도가니 (STS430 steel)에서 용해하였으며 15 분간 교반하고 1 분 간 안정시킨 후 상온몰드에 부어 제조하였다. 균질화처리 는 $400{ }^{\circ} \mathrm{C}$ 에서 20 시간 수행하였고 시효처리는 $160{ }^{\circ} \mathrm{C}$ 에서 96시간까지 열처리를 수행하였으며 열처리 후 수냉하였다. 압출공정은 곡률형 다이를 사용하여 직접압출을 수행하였 으며 압출온도는 $180^{\circ} \mathrm{C}$, 압출비는 $39: 1$, 압출속도는 0.1 $\mathrm{mm} / \mathrm{s}$ 로 수행되었다. 압출을 수행하기 전 빌렛은 압출온 도와 같은 $180{ }^{\circ} \mathrm{C}$ 까지 열처리하였으며 예열시간은 20 분 소 요되었다.

\section{2. 조직 분석}

합금의 미세조직 관찰시편은 $\Phi 8 \times 10 \mathrm{~mm}$ 크기로 제작하 였고 사포로 \#1000, \#2000, Diamond spray (3 um, 1 $\mathrm{um}, 0.25 \mathrm{um})$ 의 순서로 기계적 연마를 수행하였다. 미세조 직 관찰은 광학현미경 $(\mathrm{OM}, \mathrm{ZEISS})$ 과 주사전자현미경 (SEM, FEI; Inspect F)을 이용하였다. 그리고 석출상 분석 을 위하여 super Energy Dispersive Spectroscopy (EDS) 가 설치된 투과전자현미경 (TEM, FEI; Talos F200X)을 사용하였으며 TEM 초박막 시편은 $\mathrm{Ar}$ 밀링 (Gatan; Precision Ion Polishing System)으로 준비하였다.

\section{3. 물성 평가}

합금의 물성은 경도시험을 통하여 평가하였으며 경도계 는 MITUTOYO사의 HM- 200 을 이용하였다. 경도시험용 시편은 공정조건별로 $\Phi 8 \times 60 \mathrm{~mm}$ 크기로 가공하였고 경도 시험 시 하중은 $100 \mathrm{~g}$ 으로 하였으며 10 개 위치에서 경도 를 측정한 다음 평균값을 취하였다.

\section{3. 결과 및 고찰}

\section{1. 조직 및 조성}

그림 1(a)-(d)는 각각 시효처리 전/후, 압출공정에서 얻은 $\mathrm{Mg}-3 \mathrm{wt} \% \mathrm{Zn}$ 합금의 미세조직을 보여주는 광학현미경 이 미지이다. 그림 1(a)-(b)는 시효처리 전/후의 미세조직 이미 지이며 이미지로부터 시효처리 전/후 결정립의 크기는 변 함이 없음을 알 수 있다. 그림 $1(\mathrm{c})$ 는 $\mathrm{Mg}-3 \mathrm{wt} \% \mathrm{Zn}$ 합 

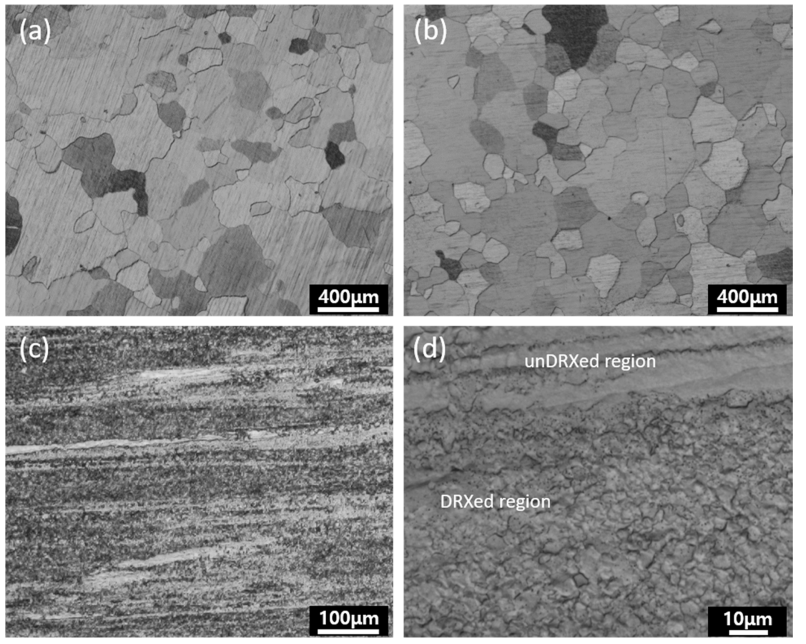

Fig. 1. Optical micrographs showing microstructures of $\mathrm{Mg}-3 \mathrm{wt} \%$ $\mathrm{Zn}$ alloys (a) before and (b) after aging at $160{ }^{\circ} \mathrm{C}$ for 96 hours, (c) \& (d) extruded at $180^{\circ} \mathrm{C}$ at low \& high resolution.

금 압출재의 저배율 미세조직 이미지이며 압출재는 압출방 향을 따라 변형된 결정립 (unDRXed grain)과 동적재결정 (dynamic recrystallization-DRX)에 의하여 형성된 미세한 결정립으로 구성된 bi-modal 결정조직을 가짐을 알 수 있 다. 그림 $1(\mathrm{~d})$ 는 $\mathrm{Mg}-3 \mathrm{wt} \% \mathrm{Zn}$ 합금 압출재의 고배율 광 학현미경 미세조직 이미지이며 이미지로부터 DRXed region 결정립의 크기가 $10 \mu \mathrm{m}$ 미만임을 알 수 있다. 그림 2(a)-(d)는 각각 주조재, 균질화처리 후, 시효처리 후, 압출 공정에서 얻은 $\mathrm{Mg}-3 \mathrm{wt} \% \mathrm{Zn}$ 합금의 주사전자현미경 이미 지이다. 그림 2(a)에서 볼 수 있는 바와 같이 $\mathrm{Mg}-3 \mathrm{wt} \%$ $\mathrm{Zn}$ 합금의 주조재 조직에서 대다수의 정출상들은 결정립 입계에 정출되었고 일부 정출상들만 결정립 입내에 정출되 었음을 알 수 있다. 주조 시 형성된 정출상은 균질화처리 를 거쳐 전부 기지에 고용시킬 수 있었다 (그림 2(b)). 그 림 2(c)는 $160{ }^{\circ} \mathrm{C}$ 에서 시효처리를 한 $\mathrm{Mg}-3 \mathrm{wt} \% \mathrm{Zn}$ 합금 의 미세조직을 보여주고 있다. 이미지로부터 석출상들이 결 정립 입계에 석출되어 있으며 입내에서는 석출상이 확인되 지 않음을 알 수 있다. 그림 2(d)는 압출재의 미세조직을 보여주고 있으며 광학현미경에서 나타낸 bi-modal결정립조 직을 확인할 수 있다. 석출상들은 DRXed region에 다량 으로 분포되어 있으며 사이즈가 큰 결정립보다 사이즈가 작은 결정립 영역에 상대적으로 더 많은 석출상들이 형성 되어 있음을 알 수 있다.

그림 3 은 시효처리를 한 주조재와 압출재의 고배율 주사 전자현미경 이미지이다. 그림 3(a)는 그림 2(c)에 표기된 영역을 보여주는 고배율 미세조직 이미지이다. 이미지로부
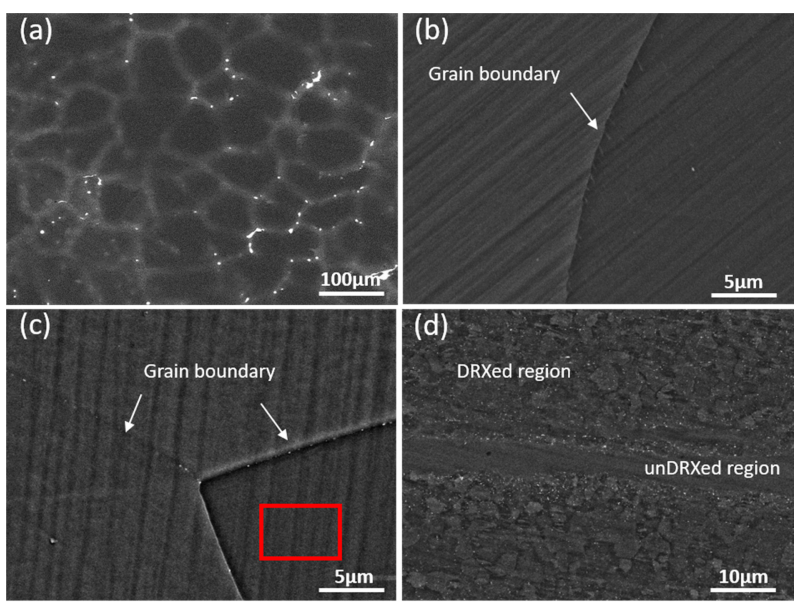

Fig. 2. SEM micrographs showing microstructures of Mg-3 wt $\% \mathrm{Zn}$ alloys, (a) as cast, (b) homogenized at $400{ }^{\circ} \mathrm{C}$ for 20 hours, (c) aged at $160{ }^{\circ} \mathrm{C}$ for 96 hours, (d) as extruded at $180{ }^{\circ} \mathrm{C}$.
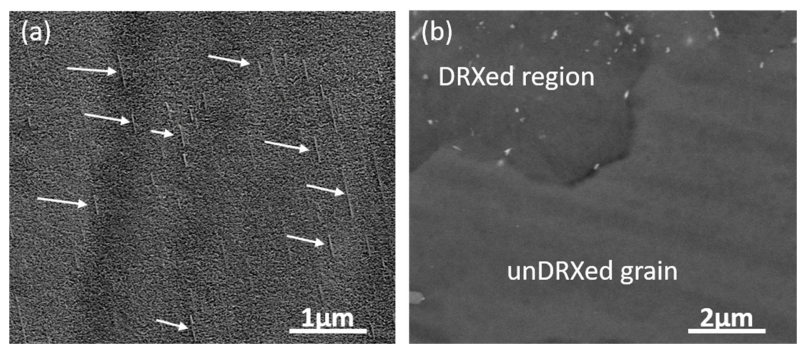

Fig. 3. High resolution SEM micrographs of Mg-3 wt $\% \mathrm{Zn}$ alloys (a) after aging at $160{ }^{\circ} \mathrm{C}$ for 96 hours and (b) as extruded at $180{ }^{\circ} \mathrm{C}$.

터 결정립 입내에 나노사이즈의 rod-like 상들이 석출이 되 어있음을 확인할 수 있다. 하지만 압출재에서는 주조재와 달리 rod-like 상은 보이지 않고 구형모양의 석출상들만 형 성되어 있다 (그림 3(b)). $\mathrm{Mg}-\mathrm{Zn}$ 합금을 시효처리한 주조 재에서 석출되는 rod-like 상은 C.L. Mendis et. al. 연구 팀에 의해 보고되었으며 $\mathrm{MgZn}_{2}$ 상으로 확인되었다 [3]. Y.Z. $\mathrm{Du}$ et. al. 연구팀은 $\mathrm{Mg}-4.5 \mathrm{wt} \% \mathrm{Zn}-1.13 \mathrm{wt} \% \mathrm{Ca}$ 합금의 동적석출거동에 대한 연구를 진행하였다. 저자는 석출이 고 용원소의 확산속도와 연관되어 있으며 고용원소의 확산속 도는 온도와 전위의 영향을 받는다고 주장하였다. 특히, 동 적석출에서 소성변형과정에 형성된 전위가 고용원소의 확 산에 필요한 채널을 만들어주는 역할을 하였다고 주장하였 다 [18]. 본 연구의 실험결과로부터 주조재의 정적석출에 서 석출상의 형성과 분포는 주로 온도의 영향을 받으며 결 정립 입계의 근체에 고용된 $\mathrm{Zn}$ 는 결정립 입계에 확산되어 $100 \sim 300 \mathrm{~nm}$ 의 제2상들을 석출하고 결정립 입내에는 직경 이 30 50 nm인 rod-like 상들이 형성되었음을 확인할 수 있다. 하지만 동적석출에서는 합금의 소성변형과정에 형성 
된 전위의 축적과 $\mathrm{DRX}$ 에 의한 전위의 해소가 석출상의 형성과 분포에 주요한 영향을 일으키며 전위의 형성, 축적 과 해소의 변화가 많이 일어난 DRXed region에 구형의 석출상들이 형성됨을 알 수 있다. 또한 DRXed region에 서 결정립의 크기가 상대적으로 작은 영역에서 석출상들이 크고 선명하지만 결정립의 크기가 상대적으로 큰 영역의 석출상들은 작고 희미하다. DRXed region에서 결정립의 크기가 서로 다른 이유는 석출상의 분포과 Zenner pinning 의 효과이다. 소성변형 과정에 형성된 석출상, 특히, 결정립 입계에 형성된 석출상은 결정립의 성장을 지연시키는 pinning작용을 하는데 이를 Zener pinning효과라고 한다 [27]. 압출 중 전위가 상대적으로 많이 형성되고 축적된 영 역에서는 재결정의 핵형성과 석출상의 핵형성이 활발하게 일어난다. 단 재결정 핵의 성장은 석출상의 pinning 효과 에 의하여 성장속도가 지연된다. 하지만 전위가 상대적으 로 적게 형성되고 축적된 영역에서는 재결정의 핵형성이 상대적으로 저조하며 석출상의 핵형성도 저조하게 된다. 반 대로 결정립의 성장은 석출상의 pinning 효과에 의한 영향 이 적어 성장속도가 상대적으로 빠르다. 때문에 DRXed region에서 결정립의 크기가 상대적으로 작은 영역의 석출 상들은 크고 선명하며 결정립의 크기가 상대적으로 큰 영 역의 석출상들은 작고 희미하다.

\section{2. 석출상 분석}

그림 4는 $\mathrm{Mg}-3 \mathrm{wt} \% \mathrm{Zn}$ 압출재의 고각 암시야 주사투 과전자현미경 (High-angle annular dark-field scanning transmission electron microscopy; HAADF-STEM) 이미 지와 제한 시야 회절패턴 (Selected area diffraction pattern, SADP)분석결과이다. 그림 4(a)-(d)는 4개의 서로 다른 위치에서 분석한 석출상을 나타내었으며 이미지에 표 기한 9 개의 석출상의 조성은 표 1 에 나타내었다. TEM 이미지로부터 석출상의 크기가 $100 \mathrm{~nm}$ 이하이고 $\mathrm{EDS}$ 결과 (표 1)와 SADP분석결과 (그림 4(b) \& 그림 4(d))로부터 두가지 석출상을 확인할 수 있다. 하나는 $\mathrm{MgZn}_{2}$ 상이고 다 른 하나는 $\mathrm{Mg}_{7} \mathrm{Zn}_{3}$ 상이다. 여기서 $\mathrm{Mg}_{7} \mathrm{Zn}_{3}$ 상은 고온에서 석출되는 상으로는 보고 되었지만 소성변형과정에 석출되 었다는 실험결과는 보고된 바가 없다. SADP분석결과 $\mathrm{Mg}_{7} \mathrm{Zn}_{3}$ 상의 결정구조는 orthorhombic 결정 구조임을 알 수 있으며 이는 G. Shao et. al. [14]이 분석한 $\mathrm{Mg}_{7} \mathrm{Zn}_{3}$ 상 의 결정구조와 일치한다. $\mathrm{Mg}_{7} \mathrm{Zn}_{3}$ 상은 준안정상으로 $200^{\circ} \mathrm{C}$ 이상에서는 $\alpha(\mathrm{Mg})+\mathrm{MgZn}$ 으로, $200^{\circ} \mathrm{C}$ 이하에서는 $\alpha(\mathrm{Mg})$ $+\mathrm{MgZn}_{2}$ 상으로 분해된다고 보고되어 있다 [26]. 하지만 L.Y. Wei et. al. 연구팀의 연구에 의하면 $\mathrm{Mg}_{7} \mathrm{Zn}_{3}$ 상은
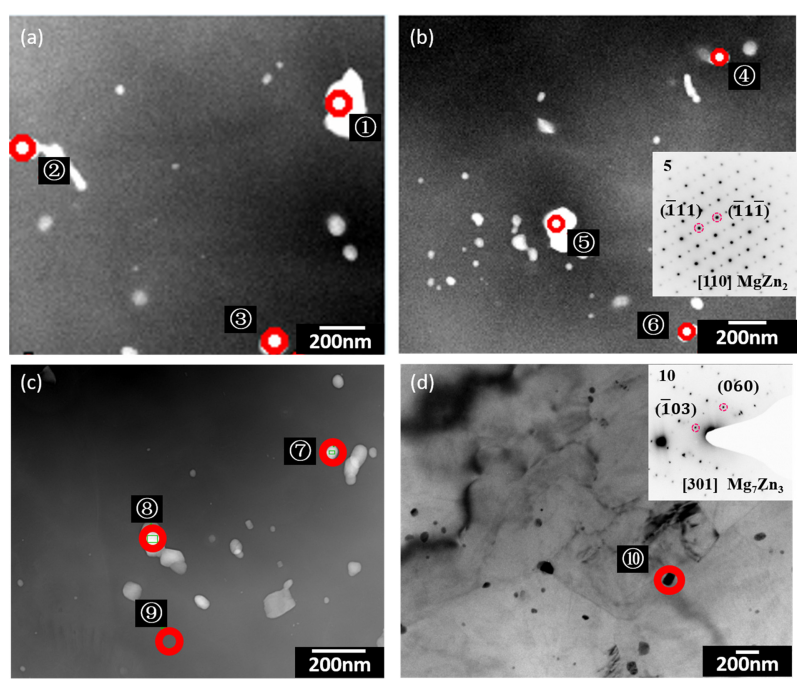

Fig. 4. TEM micrographs showing precipitates microstructures \& SADP results of as extruded Mg-3 wt $\% \mathrm{Zn}$ alloy at point (a), (b), (c), (d).

Table. 1. EDS results of the precipitates marked by red circles in Fig. 4.

\begin{tabular}{cccl}
\hline No. & $\mathrm{Mg}$ & $\mathrm{Zn}$ & Remark \\
\hline 1 & 58.89 & 41.1 & \\
2 & 60.38 & 39.61 & $\mathrm{Mg}_{7} \mathrm{Zn}_{3}$ \\
3 & 78.46 & 21.53 & \\
4 & 80.81 & 19.18 & \\
5 & 37.79 & 62.2 & $\mathrm{MgZn}_{2}$ \\
6 & 70.63 & 29.36 & \\
7 & 79.35 & 20.65 & $\mathrm{Mg}_{7} \mathrm{Zn}_{3}$ \\
8 & 74.83 & 25.17 & \\
9 & 98.57 & 1.43 & $\operatorname{Matrix}$ \\
\hline
\end{tabular}

$315^{\circ} \mathrm{C}$ 에서 완전히 분해되며 분해산물은 $\alpha(\mathrm{Mg})+\mathrm{MgZn}_{2}$ 상이라고 하였다 [27]. K. Yan et. al.연구팀은 $200{ }^{\circ} \mathrm{C}$ 에서 장시간 시효처리 시 $\mathrm{MgZn}_{2}$ 상이 안정하다고 주장하였으며 [16] Y.P. Xie et. al. 연구팀의 연구에 의하면 $\mathrm{MgZn}_{2}$ 상과 $\mathrm{Mg}_{4} \mathrm{Zn}_{7}$ 상이 상대적으로 안정하며 안정성은 고용원소의 영 향을 받는다고 하였다 [28]. $\mathrm{Mg}_{7} \mathrm{Zn}_{3}$ 상의 분해산물에 대한 연구는 추가적인 연구와 고찰이 필요한 것으로 보이지만 $\mathrm{Mg}_{7} \mathrm{Zn}_{3}$ 상이 $\mathrm{MgZn}_{2}$ 상이나 $\mathrm{MgZn}$ 상보다 열 안정성이 약하 며 다른 상으로 분해된다는 결과에 대해서 일치한 결론을 내리고 있다. 그러므로 단순한 열처리 공정에서는 $\mathrm{Mg}_{7} \mathrm{Zn}_{3}$ 상이 쉽게 형성되지 않음을 알 수 있다. 그림 5 는 $\mathrm{Mg}-\mathrm{Zn}$ 합금의 평형상태도를 PANDAT 프로그램으로 계산하여 나 타낸 이미지이다. 그림 5 에서 나타내었듯이 $\mathrm{Mg}_{7} \mathrm{Zn}_{3}$ 상이 
정출 또는 석출할 수 있는 온도는 $327 \sim 342{ }^{\circ} \mathrm{C}$ 로 압출온 도 $\left(180^{\circ} \mathrm{C}\right)$ 보다 $147^{\circ} \mathrm{C}$ 높다. 압출 중 변형발열과 마찰발 열로 인하여 실지 시편의 온도는 $180^{\circ} \mathrm{C}$ 보다 높을 것으로 예상된다. 하지만 $300{ }^{\circ} \mathrm{C}$ 이상으로 향상되지 않을 것으로 예상되는데 이는 압출시편의 온도가 $300{ }^{\circ} \mathrm{C}$ 이상으로 향상 되었을 시 평형상태도로부터 $\mathrm{Mg}-3 \mathrm{wt} \% \mathrm{Zn}$ 합금은 고용합 금 즉 $\mathrm{Mg}$ 에 대한 $\mathrm{Zn}$ 의 고용가능 범위내에 있기에 석출이 아니라 오히려 $\mathrm{Zn}$ 가 $\mathrm{Mg}$ 에 고용된다. 압출 시 다이를 지나 가는 압출재의 온도 즉 압출기 출구의 압출재 온도가 가장 높다 [29]. S.S. Park et. al. 연구팀은 압출조건이 압출재 의 미세조직에 미치는 영향을 연구하였으며 압출기 출구에 서 압출재의 온도는 압출온도보다 $40 \sim 90{ }^{\circ} \mathrm{C}$ 높은 온도를 가진다고 하였다 [30]. 단 저자의 압출조건에서 압출비는 $25: 1$ 로 본 실험의 압출비와 유사하지만 압출속도가 1.3 $6.7 \mathrm{~mm} / \mathrm{s}$ 로 가장 작은 압출속도가 본 실험의 압출속도인 $0.1 \mathrm{~mm} / \mathrm{s}$ 의 10 배에 가까운 속도이다. 그러므로 본 실험에 서 압출 시 압출재의 온도와 압출온도의 차이 값은 $40{ }^{\circ} \mathrm{C}$ 미만으로 $220^{\circ} \mathrm{C}$ 에 가까울 것으로 예상된다. 이는 $\mathrm{Mg}_{7} \mathrm{Zn}_{3}$ 상의 정출 시 온도보다 약 $107^{\circ} \mathrm{C}$ 낮다. 앞장에서 언급하 였듯이 제 2 상의 석출은 고용원소의 확산속도와 연관되어 있으며 고용원소의 확산속도는 온도와 전위의 영향을 받는 다. 그러므로 동적석출에서 $\mathrm{Mg}_{7} \mathrm{Zn}_{3}$ 상의 형성을 야기하는 주요한 인자는 압출과정에 형성되는 전위임을 알 수 있다. $180{ }^{\circ} \mathrm{C}$ 에서 $\mathrm{Mg}$ 에 대한 $\mathrm{Zn}$ 의 고용도가 $2.63 \mathrm{wt} \%$ (평형상 태도기준)임을 고려해볼 때 $3 \mathrm{wt} \%$ 의 $\mathrm{Zn}$ 를 고용하고 있 는 $\mathrm{Mg}-3 \mathrm{wt} \% \mathrm{Zn}$ 합금에서 $\mathrm{Zn}$ 는 $0.27 \mathrm{wt} \%$ 과포화 고용 되어 있다. 시편의 온도가 $220^{\circ} \mathrm{C}$ 까지 향상되었을 시 $\mathrm{Mg}$ 에 대한 $\mathrm{Zn}$ 의 고용도는 향상되며 과포화 고용된 $\mathrm{Zn}$ 의 양 은 더 줄어든다. 그러므로 아주 적은 양의 $\mathrm{Zn}$ 만이 석출에 참여하게 된다. 그뿐만 아니라 급격한 소성변형 (압출비 39:1)에 의하여 동시다발적으로 전위의 형성, 이동과 축적 이 활발하게 일어나며 전위는 고용원소의 확산속도를 향상 시킴과 동시에 이를 해소하기 위한 재결정의 핵생성을 유 도한다. 과포화 고용되었던 소량의 $\mathrm{Zn}$ 는 활발한 전위의 활 동과 더불어 제 2 상의 핵형성에 참여하게 되지만 아주 불 안정한 상태이다. 이는 시효처리를 한 주조재 (그림 1(b) \& 그림 2(c))와 압출재 (그림 1(d) \& 그림 2(d))의 결정 립의 상태로부터 도출할 수 있다. 시효처리를 한 주조재의 결정립 입계는 아주 안정한 라인을 이루고 있지만 압출재 의 결정립 입계는 일정한 라인을 갖추지 않았거나 톱이모 양으로 아주 불규칙적인 모양을 하고 있는데 이는 압출재 의 결정립 입계에서는 원자운동이 활발하고 불안정한 상태 임을 알 수 있다. 활발한 움직임을 가진 $\mathrm{Zn}$ 는 그 상태가

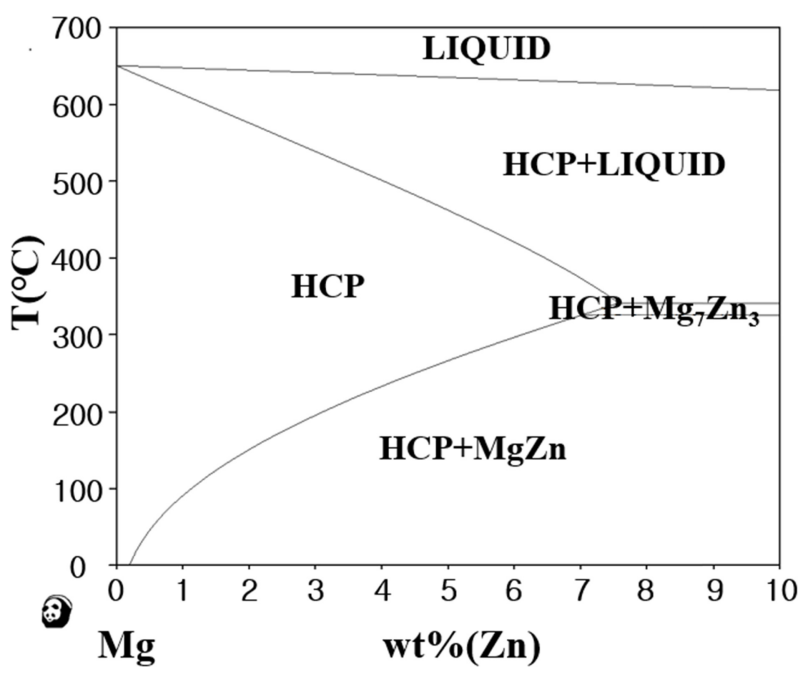

Fig. 5. The equilibrium phase diagram of Mg-Zn alloy calculated by PANDAT software based on the CALculation of PHAse Diagram (CALPHAD).

불안정하였으며 석출에 참여한 양도 미량이 였기에 저온안 정상인 $\mathrm{MgZn}$ 상이나 $\mathrm{MgZn}_{2}$ 상을 형성하지 못하고 $\mathrm{Mg}$-rich 한 상인 $\mathrm{Mg}_{7} \mathrm{Zn}_{3}$ 상이 석출하게 된다. 또한 저온에서 안정 한 $\mathrm{Zn}$-rich한 상인 $\mathrm{MgZn}$ 상이나 $\mathrm{MgZn}_{2}$ 상으로 분해되기에 는 압출시간이 충분히 길지 않았다. 즉 압출과정의 큰 소 성변형속도와 미량의 $\mathrm{Zn}$ 및 짧은 압출공정 시간이 불안정 한 $\mathrm{Mg}_{7} \mathrm{Zn}_{3}$ 상의 형성에 기여한 것으로 분석된다. 선행연구 에서 $\mathrm{Mg}-\mathrm{Zn}$ 합금의 동적석출에 대한 연구는 석출에 참여 할 수 있는 $\mathrm{Zn}$ 의 양이 상대적으로 많았고 $(\mathrm{Mg}-6 \mathrm{wt} \%$ $\mathrm{Zn}[16,17])$ 압출온도가 높았을 뿐만 아니라 $\left(200{ }^{\circ} \mathrm{C}[16]\right.$, $300{ }^{\circ} \mathrm{C}$ [17]) 소성변형속도가 작아 (압출비 $16: 1$ [10], 압 출비 12:1 [17]) 소성변형에 의하여 형성된 전위는 $\mathrm{DRX}$ 에 의하여 충분히 해소될 수 있었기에 $\mathrm{Mg}_{7} \mathrm{Zn}_{3}$ 상의 핵형성 을 야기할 수 없었다. 본 실험에서 압출재의 석출상에는 소량의 $\mathrm{MgZn}_{2}$ 상 (그림 4(b))도 확인되었는데 이는 일부 $\mathrm{Mg}_{7} \mathrm{Zn}_{3}$ 상이 분해된 산물일 것으로 분석된다. 즉 $\mathrm{Mg}-\mathrm{Zn}$ 합 금의 동적석출에서 제2상은 $\mathrm{ssss} \rightarrow \mathrm{Mg}_{7} \mathrm{Zn}_{3} \rightarrow \mathrm{MgZn}_{2}$ 의 순서로 석출됨을 도출할 수 있다.

\section{3. 기계적 물성}

그림 6 은 주조재의 시효처리 전/후 및 압출재의 경도값 을 그래프로 나타낸 이미지이다. Mg-3wt $\% \mathrm{Zn}$ 합금의 주 조재는 시효처리를 하면 경도가 $51.5 \mathrm{HV}$ 에서 $59.6 \mathrm{HV}$ 로 향상된다. 이는 $\mathrm{Mg}-3 \mathrm{wt} \% \mathrm{Zn}$ 합금을 시효처리 후 정적석 출에 의한 석출강화 효과이다. $\mathrm{Mg}-3 \mathrm{wt} \% \mathrm{Zn}$ 합금 압출재 의 경도는 $81.5 \mathrm{HV}$ 로 대폭 항상되었는데 이는 주조재의 


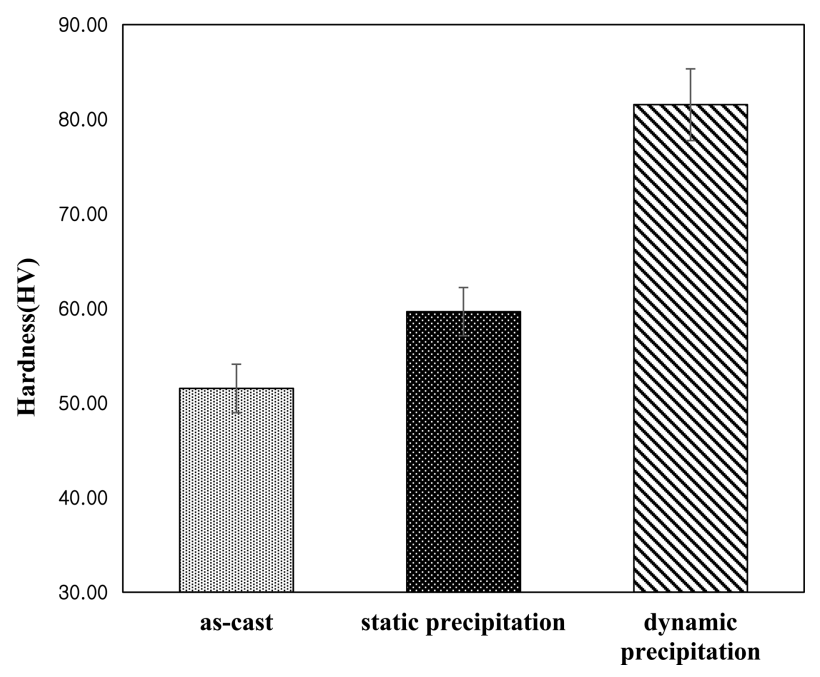

Fig. 6. Vickers hardness comparison results of $\mathrm{Mg}-3 \mathrm{wt} \% \mathrm{Zn}$ alloys.

$58.2 \%$, 시효처리를 한 주조재의 $36.7 \%$ 향상 된 결과이다. 이는 $180{ }^{\circ} \mathrm{C}$ 에서 $\mathrm{Mg}-3 \mathrm{wt} \% \mathrm{Zn}$ 합금을 압출하면 다량의 전위의 발생과 이동이 일어나며 이에 따라 재결정의 핵이 형성됨과 동시에 석출상의 핵이 형성된다. 재결정에 의하 여 형성된 결정립의 성장은 낮은 온도와 결정립 입계에 형 성된 석출상의 pinning 효과로 인해 결정립의 성장속도가 느려진다. 때문에 재결정에 의하여 마이크로사이즈의 결정 립과 변형된 unDRXed 결정립으로 구성된 bi-modal 결정 조직이 형성된다. 이와 같은 이유로 $\mathrm{Mg}-3 \mathrm{wt} \% \mathrm{Zn}$ 합금의 저온압출은 단시간 내에 결정립미세화에 따른 입계에 의한 강화와 동적석출에 의한 석출강화의 효과를 동시에 가져와 기계적 물성의 향상되는 반면 공정시간이 짧아 산업의 생 산성을 대폭 향상시킬 수 있을 것으로 예상된다.

\section{4. 결 론}

본 연구에서는 상대적으로 $\mathrm{Zn}$ 함량이 적은 $\mathrm{Mg}-3 \mathrm{wt} \%$ $\mathrm{Zn}$ 합금이 저온압출 과정에 발생하는 동적석출 거동에 대 해 고찰하였다. $\mathrm{Mg}-3 \mathrm{wt} \% \mathrm{Zn}$ 합금의 압출재는 $\mathrm{DRXed}$ region과 unDRXed region으로 구성된 bi-modal 미세조직 을 가지며 이는 $\mathrm{DRX}$ 와 동적석출의 복합적인 영향을 받은 결과이다. 동적석출에 의한 석출상은 orthorhombic의 $\mathrm{Mg}_{7} \mathrm{Zn}_{3}$ 상이며 낮은 온도와 소성변형과정에 발생한 전위가 $\mathrm{Mg}_{7} \mathrm{Zn}_{3}$ 상의 석출에 기여한 것을 분석된다. 저온압출에서 동적석출은 석출강화로 압출재의 물성향상에 기여할 뿐만 아니라 짧은 공정시간은 산업의 생산성을 대폭 향상시킬 수 있을 것으로 예상된다.

\section{감사의 글}

이 연구는 산업통상자원부 (MOTIE, Korea)가 후원하는 산업전략기술개발프로그램 (10077595)의 지원을 받아 수행 되었다.

\section{REFERENCES}

1. L. Wang, Y. Q. Zhao, H. M. Chen, J. Zhang, Y. D. Liu, and Y. N. Wang, Acta Metall. Sin. (Engl. Lett.) 31, 63 (2018).

2. M. Álvarez-Leala, A. Orozco-Caballero, F. Carreñoa, and O. A. Ruanoa, Mater. Sci. Eng. A 710, 240 (2018).

3. C. L. Mendis, K. Oh-ishi, and K. Hono, Scripta Mater. 57, 485 (2007).

4. S.-H. Kim, J. U. Lee, Y. J. Kim, J. O. Choi, J.-H. Lee, and S. H. Park, Korean J. Met. Mater. 56, 40 (2018).

5. S. W. Lee, S.-H. Kim, and S. H. Park, Korean J. Met. Mater. 56, 699 (2018).

6. X. Jin, W. Xu, D. Shan, C. Liu, and Q. Zhang, Met. Mater. Int. 23, 434 (2017).

7. C.-F. Yue, S.-J. Huang, J.-K. Chen, H.-T. Li, K.-S. Chan, Met. Mater. Int. 24, 301 (2018).

8. S. H. Jeong, Y. J. Kim, K. H. Kong, T. H. Cho, Y. K. Kim, H. K. Lim, W. T. Kim, and D. H. Kim, Met. Mater. Int. 24, 381 (2018).

9. J. U. Lee, S.-H. Kim, W.-K. Jo, W.-H. Hong, W. Kim, J. H. Bae, and S. H. Park, Met. Mater. Int. 24, 730 (2018).

10. J. M. Rosalie, A. Singh, H. Somekawa, and T. Mukai, Phil. Mag. A 91, 19 (2012).

11. G. S. Hu, D. F. Zhang, Y. F. Dong, X. Chen, L. Y. Jiang, and F. S. Pan, Trans. Nonferrous Met. Soc. China 25, 1439 (2015).

12. Y. L. Zhou, Y. C. Li, D. M. Luo, Y. F. Ding, and P. Hodgson, Mater. Sci. Eng. C 49, 93 (2015).

13. G. Hu, B. Xing, F. Huang, M. Zhong, and D. Zhang, Mater. Sci. and Tech. 33:3, 294 (2017).

14. G. Shao, V. Varsani, Y. Wang, M. Qian, and Z. Fan, Intermetallics 14, 596 (2006).

15. E. Dogan, S. Wang, M. W. Vaughan, and I. Karaman, Acta Mater. 116, 1 (2016).

16. K. Yan, J. Bai, H. Liu, and Z. Y. Jin, J. Magnes. Alloy 5, 336 (2017).

17. J. M. Rosalie, H. Somekawa, A. Singh, and T. Mukai, Phil. Mag. 90:24, 3355 (2010).

18. Y. Z. Du, M. Y. Zheng, B. L. Jiang, and K. S. Zhou, JOM 70, 1611 (2018). 
19. X. L. Hou, Z. Y. Cao, L. D. Wang, S. W. Xu, S. Kamado, and L. M. Wang, Mater. Sci. Eng. A 528, 7805 (2011).

20. X. L. Hou, Q. M. Peng, Z. Y. Cao, S. W. Xu, S. Kamado, L. D. Wang, Y. M. Wu, and L. M. Wang, Mater. Sci. Eng. A 520, 162 (2009).

21. I. A. Anyanwu, S. Kamado, and Y. Kojima, Mater. Trans. 42, 1206 (2001).

22. J. L. Yan, Z. J. Qin, and K. Yan, Metals 8, 841 (2018).

23. K. Yan, J. P. Sun, J. Bai, H. Liu, X. Huang, Z. Y. Jin, and Y. N. Wu, Mater. Sci. Eng. A 739, 513 (2019).

24. M. Rashad, F. S. Pan, and M. Asif, Mater. Sci. Eng. A 649, 263 (2016).

25. F. J. Humphreys and M. Hatherly, Recrystallization and
Related Annealing Phenomena, $2^{\text {nd }}$ ed., pp. 114, Elsevier, Kidlington (2004)

26. W. J. Kitchingman and I. M. Vesey, J. Inst. Met. 98, 52 (1970).

27. L. Y. Wei, G. L. Dunlop, and H. Westengen, Metall. Mater. Trans. A 26A, 1947 (1995).

28. Y. P. Xie, Z. Y. Wang, and Z. F. Hou, Scripta Mater. 68, 495 (2013).

29. L. Li, J. Zhou, and J. Duszczyk, J. Mater. Process. Tech. 145, 360 (2004).

30. S. S. Park, B. S. You, and D. J. Yoon, J. Mater. Process. Tech. 209, 5940 (2009). 